\title{
Social Harmony in Local Cultural Awareness, Its Effect on Conflict Settlement and Social Violence (Case Study of Silat College Conflict in Madiun)
}

\author{
Sudjatmoko $^{1}$ Hery Hermawan ${ }^{2}$ Retno Iswati ${ }^{1}$ \\ 1.Faculty of Social Sciences and Political Sciences, Merdeka Madiun University, Indonesia \\ ${ }^{2}$ Faculty of economics, Merdeka Madiun University, Indonesia
}

\begin{abstract}
The conflict between the two silat colleges in Madiun, was caused by differences in opinions and interests of individuals related to the strategy of developing the values of the faithful heart of the martial arts school. Settlement efforts have been carried out by the authorities through reconciliation by bringing together conflicted parties, however, the implementation of reconciliation was not effective in resolving the conflicts that occurred. Solutions that prioritize prosecution actually lead to new problems, therefore a cultural approach can be a support for resolving these social conflicts. Local cultural wisdom that contains values, social norms, and goals binds the community in maintaining harmony, harmony and harmony of social life. These social values and norms form the glue of people's lives and are believed to be able to solve social problems that occur in society. With the use of local culture, it will be able to encourage living together in the community based on the demands of a value system that complements their rules culturally.
\end{abstract}

Keywords: Silat College, Conflict, Harmony, Culture, Local Wisdom.

DOI: $10.7176 /$ RHSS/10-18-05

Publication date:September $30^{\text {th }} 2020$

\section{BACKGROUND}

As a social being, each individual always carries out social interaction both within the group and outside the group, and in the continuity of social interaction, it often creates clashes or opposing opinions which can lead to social conflict. Likewise, the conflict between the two silat schools between the Persaudaraan Setia Hati Terate (SH. Terate) and the Setia Hati Winongo Tunas Muda Brotherhood (SH. Winongo), started because of disagreements related to the strategy of developing the values of the loyal heart silat school teachings, on the one hand. argues that it is necessary to strictly accept new membership in order to maintain the quality of its teachings, but on the other hand wants to want the spread of teaching values loosely so that they can be widely spread in the community. This difference of opinion grew and became sharper after the differences in the orientation of political interests after the G30S PKI involving the warriors of Setia Hati Terate (SH. Terate) and Setia Hati Winongo Tunas Muda (SH. Winongo), and often involved in physical clashes that cause casualties.

The conflict between the two silat schools in Madiun has led to the danger of latenization, because in addition to being carried out at certain moments it also takes place sporadically outside of these activities. The moments that are prone to conflict include: (1) Suran Agung, as the annual agenda for the SH Winonga silat college to welcome the coming of the month of Suro or Muhharam as a form of gratitude to God Almighty. In that event, a ritual of enjoying "porridge suro" is carried out and a connection ceremony from fellow members of the school. However, the vulnerability of social conflict has resulted in physical clashes in the convoy activities of the SH Winongo silat college members, and it is on the convoy route that often becomes an arena for mass clashes. (2). Halal Bihalal, as a routine agenda which is held annually by the Winongo Tunas Muda Brotherhood of Setia Hati as a form of establishing silahturami which is attended by all branches of the SH Winongo martial arts school. This activity often invites conflict vulnerability that leads to physical violence, either by members of the SH Winongo silat school or by other less sympathetic parties. (3) Ratification of New Members, which is a routine activity held by the SH Terate silat school as a form of legalizing new memberships to become citizens. In this activity, it also invites conflict vulnerability that has the potential for physical violence because in this activity a convoy is carried out and usually invites provocative action to commit several acts of physical violence which cause victims (Soebijantoro et al, 2012).

In a sociological perspective, it is a reality in the relationship between humans that is not free from social conflict, however, not every conflict is interpreted as destructively (negatively) but understanding social conflict also has constructive (positive) benefits. Destructive conflict is a conflict that results in unfavorable consequences for the conflicting parties. Destructive conflict can result in loss of life, property, competition, feelings of anxiety and so on. Destructive conflict can occur because of feelings of displeasure or hate. Meanwhile, destructive conflict is a conflict that occurs because of differences of opinion in dealing with a problem. Constructive conflict is able to lead to constructive benefits and consequences, this conflict is functional. The results of constructive conflict include producing a consensus or agreement from these differences so as to produce an improvement. Constructive 
conflict can produce benefits including increased initiative and creativity, and the reduction of personal tension (http://sosiologis.com/struktur-social). The formation of a human or community unit begins with social association (equality) and dissociation (inequality) which is manifested in cooperation, on the one hand and also social conflict, on the other hand which occurs repeatedly. Based on this fact, it can be believed that through social conflict a community group can be formed and always strives to maintain their identity or group identity which is clearly visible when a group conflicts with another group. In the theory of conflict, according to Ralf Dahrendorf, he views society as a social system consisting of different interests where there is an attempt to conquer other components in order to fulfill other interests or gain the maximum interest. Social conflict, if it cannot be resolved, will become a threat to social life because conflict can lead to social violence that disturbs the comfort of community life. According to Robert Audi in Setiadi and Kolip (2010: 358), violence is as an attack or physical abuse of a person or very violent, violent attack, destruction, destruction. Cruel, and malignant to property or something that could potentially belong to someone.

Conflicts between silat schools in Madiun have also led to forms of social violence, this can be seen from the incidents of clashes between silat college members that often lead to mass clashes and invite concern from the community. Various attempts have been made by the authorities by involving Muspida and community leaders to reconcile the two silat schools by bringing together their administrators to find wise and appropriate solutions. However, the reconciliation has not been effective because until now there are still physical clashes between the two silat schools. However, the complexity of the problems that occur must be able to be resolved wisely and wisely oriented towards balance and harmony in order to create an atmosphere of harmony and harmony in people's lives. In general, society has a culture that contains social values and norms that serve as guidelines for each individual to carry out various activities and at the same time can be used as a basis for resolution in the event of a dispute in the community environment. For this reason, conflict resolution between silat colleges can be done through a cultural approach, because the legal approach has so far been less effective in resolving it completely. Local cultural wisdom has advantages because it has become the glue in people's lives so that reconciliation will be easier to achieve because each group upholds the values of togetherness. Javanese cultural values, especially noble teachings, also form the basis of the two silat schools of the Setia Hati Terate and Persaudaraan Setia Hati Winongo Tunas Muda as references to behave in the midst of social life. Social harmony is the virtue of having an attitude and always upholding it in realizing a safe and secure life. Local cultural wisdom can be an alternative solution to social conflicts, local policies that are rooted and considered sacred, causing their implementation to be more efficient and effective because they are easily accepted by the community. Local wisdom has the potential to encourage people's desire to live in harmony and peace. Local traditions and culture generally teach peace to live in harmony with their social environment (www.pengentukmenurutahli.net/pengentuk-kearifanlokal-secaraumum/). Approach to local cultural wisdom by utilizing the values that have been owned by each group / community environment, as the main points of thought in every day-to-day implementation of values, ethics, and behavior that have traditionally been institutionalized. Living together in a community environment based on the guidance of a value system, is an indication that culturally complementing their rules with a number of local policies can strengthen cohesion for an integrated social life. The processes that take place have the purpose and objective of observing as an act of alertness to various possible problems caused by misunderstanding or friction due to inequality.

Paying attention to the compliance of residents with applicable values, norms and regulations, of course the local wisdom approach in an effort to resolve social conflicts that occur can be a strategic medium to find solutions, if the parties involved in resolving the conflict have a good commitment to wisdom. local and consistent in carrying out its position, role and function. For this reason, the parties involved in efforts to resolve social conflicts that occur must have the ability to invite the parties involved in the social conflict to meet, have an open dialogue through discussions in order to negotiate the desires between each party involved in the conflict. referred to. Activities in the form of efforts to resolve social conflicts that occur, directly and / or indirectly affect the possible and appropriate forms of resolution, and can be used as an early warning against conflicts or a conflict early warning system.

\section{LITERATURE REVIEW.}

Conflict is a social symptom that is always present in social life, so that conflict is inherent, meaning that conflict will always exist in every space and time, anywhere and anytime. In this view, society is an arena of conflict or an arena of ongoing conflict and integration. Therefore, conflict and social integration are symptoms that always fill every social life. The things that encourage conflict and integration are the similarities and differences in social interests. In every social life there is not a single human being who has exactly the same thing, whether from the elements of ethnicity, interests, will, will, goals, and so on. From each conflict, some of them can be resolved, but some cannot be resolved, resulting in several acts of violence. Violence is a symptom of the inability to overcome the root of conflict, causing violence from the smallest model to war (Setiadi and Kolip, 2010: 347).

Etymologically, the term conflict comes from the Latin "configure" which means collision or collision. So 
conflict can be interpreted as differences that lead to conflicts or disputes between group members and / or society in the form of physical confrontation between several parties. This is a result of the absence of a meeting point for differences in the interests of the two parties which are considered as something that must be fought for. According to Soekanto (2006: 91), that: conflict is a difference or conflict between individuals or social groups that occurs because of differences in interests, as well as efforts to fulfill goals by opposing the opposing party accompanied by threats or violence. There is no common ground between these differences which results in a conflict between the two parties to achieve their respective goals. Social conflict, in addition to being a form of effort to achieve goals but at the same time to subdue, this is as stated by Robert Lawang (1994: 53), conflict orientation is intended as a struggle to obtain rare things such as values, status, power and so on. where their goals conflict it is not only to gain profit but also to subdue its competitors. Conflict can be defined as a clash of strengths and interests between one group and another in the process of seizing relatively limited social resources (economic, political, social and cultural). In this view, conflicts in social life occur because of conflicts of interest, desires, opinions, etc. which at least involve two or more parties.

The conflict between martial arts schools in Madiun cannot be separated from conflicts of interest, desires and opinions. The differences in interests, desires and opinions can be a factor that encourages social conflict, because those interests and desires are essential for the continuity of human life. When his interests and desires can be fulfilled, it will lead to satisfaction, but on the other hand, if his interests and desires cannot be realized, it can cause problems for himself and his environment. From several views of sociologists, the root causes of social conflict include: (1) Differences in the position and beliefs of individuals have caused conflict between individuals. In conflicts like this there are clashes of opinion, and each side tries to destroy its opponent. Destroying here does not always mean physical destruction, but can also be interpreted in the form of symbolic annihilation or eliminating the thoughts of opponents who are not approved. In social reality there is not a single individual who has the same character so that differences of opinion, purpose, desire are what influence the emergence of social conflict. (2) Cultural differences. Cultural differences will not only lead to conflict between individuals, but also between groups. Different cultural patterns will lead to different personality patterns and behavior patterns among a broad group of audiences. In addition, cultural differences will result in ethnocentrism, namely the attitude shown to other groups that their group is the best. If each group in social life shares this attitude, then this attitude will lead to conflict between cultural adherents. (3) Differences of interest. Pursuing the different objectives of their respective interests, groups will compete and conflict over opportunities and means (Muarofah, 2014)

So far, social conflict has been considered bad, but basically social conflict at a certain point is also needed to encourage progress. According to Robert H. Lauer (2001: 98), based on its nature, conflict can be divided into destructive conflict and constructive conflict. (1) Destructive conflict, is a conflict that arises because of feelings of displeasure, hatred and resentment from a person or group against another party. In this conflict, physical clashes occurred which resulted in the loss of life and property. (2). Constructive conflict is a conflict that is functional in nature, this conflict arises because of differences of opinion from groups in facing a problem. This conflict will produce a consensus of the various opinions and result in an improvement. In the perspective of conflict, martial arts in Madiun can also be functional if the social conflict can be managed properly to support the progress of community development. According to Nasikun (2003: 25), there are six forms of conflict control, namely: (1). Conciliation (conciliation). This kind of control manifests itself through certain institutions which allow the growth of a pattern of discussion and decision-making among opposing parties on the issues they dispute. (2). Mediation (mediation). This form of control is carried out when both parties to a dispute mutually agree to provide advice on how they should resolve their conflict. (3). Arbitration comes from the Latin word arbitrium, which means through court, with a judge (arbiter) as the decision maker. Arbitration is different from conciliation and mediation. An arbitrator makes a decision that binds both parties to the dispute, meaning that the decision of a judge must be obeyed. If a party does not accept the decision, he can appeal from a higher court to the highest national court. (4). Arbitration. In this case, the two opposing parties agree to make certain decisions to resolve the conflict that occurs between them.

Social conflict resolution steps through these institutions have been carried out in resolving the conflict between the two silat schools in Madiun through reconciliation initiated by the authorities by bringing together the two parties who are in conflict, however the results of reconciliation in its implementation have not been effective to resolving the conflicts that occurred, because there were many cases of physical clashes committed by members of the two silat schools. For this reason, it is necessary to approach local cultural wisdom as a support for resolving social conflicts that occur, because local cultural wisdom is habits that are believed to be true by the community and have become a tradition inherent in social life. Local wisdom contains values, norms and community beliefs which become the basis for solving social problems. Local wisdom as binding values through the obedience and discipline of all members of society to the norms and rules that apply in the community, has patterns and or procedures in an effort to narrow down differences in order to anticipate indications of social conflict in the community.

Starting from the above thought, that the resolution of conflict and social violence (conflict between two silat 
colleges) will be easily achieved through the approach of local cultural wisdom, because values and social norms are the basis for society to solve problems in society, so they can be constructed. the relationship between variables as a hypothesis, namely:

1. Ho $=$ There is an influence between local cultural harmony on conflict resolution and social violence (Conflict of two silat colleges)

2. $\mathrm{Ha}=$ There is no influence between local cultural harmony on conflict resolution and social violence (Conflict of two silat colleges)

\begin{tabular}{|c|c|}
\hline $\begin{array}{c}\text { Social harmony in local } \\
\text { cultural (VX) }\end{array}$ & $\begin{array}{c}\text { Conflict resolution and social } \\
\text { violence (Conflict of two silat } \\
\text { colleges) (VY) }\end{array}$ \\
\cline { 2 - 3 }
\end{tabular}

\section{RESEARCH METHODS}

This study uses a quantitative approach to determine the respondents' assessment of the accountability of the performance of the public bureaucracy, and the behavior of corruption, collusion and nepotism (KKN). Data were collected through distributing questionnaires to 120 randomly selected respondents in 6 branch management villages, Madiun Regency. Twenty respondents were assigned to each branch by random sampling, consisting of: 15 administrators and members of the silat college, and 5 communities in the community. The respondent's assessment was measured using a Likert scale with a gradation from very positive to very negative, in the form of words including: a) Strongly agree with a score of 5, b) agree with a score of 4, c) doubt with a score of 3, d) No agree with score 2, and e) Strongly disagree with score 1 . While the data analysis method uses a regression analysis model with processing through SPSS.

\section{RESULTS AND DISCUSSION.}

\section{Correlation Test}

To test the hypothesis, a correlation test was carried out between the local cultural harmony variable (VX) as the independent variable on conflict resolution and social violence (Conflict of two silat colleges) (VY) as the dependent variable. The results of the correlation test are as follows:

Table. 1

The harmonious relationship between local culture and conflict resolution and social violence (Conflict between two silat schools)

\section{Correlations}

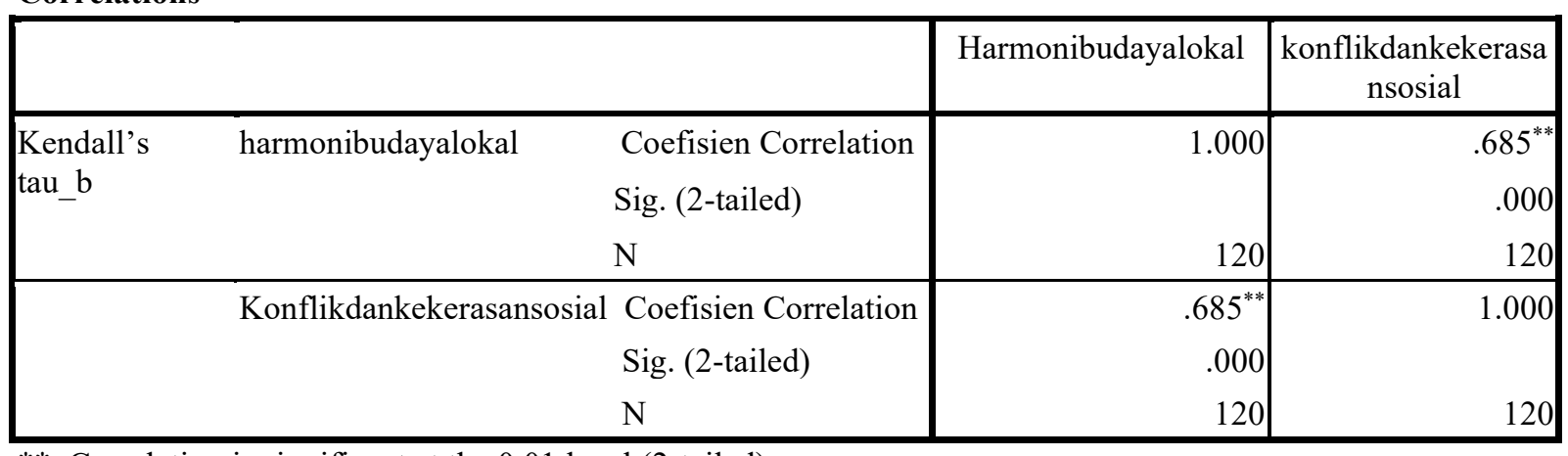

**. Correlation is significant at the 0.01 level (2-tailed).

From the table above, the correlation value between the variable local cultural harmony with the variables of conflict and social violence (conflict between two silat colleges) is 0.685 with a $p$-value $=0.000$. When compared with the value $\alpha=0.05$, it is known that pvalue $=(0.000)<\alpha(0.05)$. Thus, the hypothesis Ha is accepted, namely that there is a correlation between local cultural harmony with conflict and social violence (conflict of two silat colleges).

\section{Regression Test}

The results of the regression calculation between the variables of local cultural harmony on conflict and social violence (Conflict of two silat colleges) are: 
Table. 2

The influence of local cultural harmony

towards conflict resolution and social violence (Conflict of two silat colleges)

Coefficients $^{\mathrm{a}}$

\begin{tabular}{|c|c|c|c|c|c|}
\hline \multirow[b]{2}{*}{ Model } & \multicolumn{2}{|c|}{ Unstandardized Coefficients } & \multirow{2}{*}{$\frac{\text { Standardized Coefficient }}{\text { Beta }}$} & \multirow[b]{2}{*}{$\mathrm{t}$} & \multirow[b]{2}{*}{ Sig. } \\
\hline & B & Std. Error & & & \\
\hline 1 (Constant) & 3.904 & 3.412 & & 1.144 & .255 \\
\hline harmonibudayalokal & .861 & .058 & .80 & 14.866 & .000 \\
\hline
\end{tabular}

a. Dependent Variable: konflikdankekerasansosial

From the regression equation ( $\mathrm{Y}=\mathrm{a}+\mathrm{bX})$, it can be identified: (1) The constant value is 3.904; shows that conflict and social violence (Conflict of two silat colleges) will be constant if the variable of local cultural harmony is zero (non-existent), assuming other factors remain or do not change in value. (2) The variables of conflict and social violence (Conflict of two silat colleges) with a value of 0.861 (positive) indicate the influence of local cultural harmony on conflict resolution and social violence (Conflict of two silat colleges). If the local cultural harmony increases by 1 unit then conflict and social violence (Conflict of two silat colleges) will also decrease by 0.861. Thus local cultural harmony has a positive effect on conflict resolution and social violence (Conflict of two silat colleges).

\section{Determination Test.}

The coefficient of determination (R2) is used to measure how far the model's ability to explain variations in the dependent variable (Ghozali, 2006). The results of the determination coefficient test are:

Table 3

Results of the Determination Test between local cultural harmony variables and conflict resolution and social violence (Conflict of two silat colleges)

\section{Model Summary}

\begin{tabular}{|l|r|r|r|r|}
\hline Model & \multicolumn{1}{|c|}{ R } & \multicolumn{1}{|c|}{ R Square } & Adjusted R Square & Std. Error of the Estimate \\
\hline 1 & $.807^{\mathrm{a}}$ & .652 & .649 & 4.833 \\
\hline
\end{tabular}

a. Predictors: (Constant), kearifanbudayalokal

b. Dependent Variable: konfliksosial

The amount of Multiple Coefficient of Determination (R Square) is 0.650 or $65.0 \%$ which means conflict and social violence (conflict of two silat colleges) can be explained by the local cultural harmony variable, while the remaining $35.0 \%$ is explained by other variables which are not explained in this research. Conflict and social violence behavior is very dependent on the establishment of local culture as the glue of community life, because conflict and social violence are actions that deviate from prevailing social values and norms in order to achieve personal or group interests. The conflict between the two silat schools in Madiun will be easily resolved if the groups that are in conflict uphold the values and social norms that are binding in the life of the Madiun people in general, because this condition is in accordance with the values of teachings which are also developed in the loyal silat school. heart. Local wisdom that has become habits in daily interactions is a way of life with policies that are formed based on consensus to be implemented jointly by members of the community. If there is behavior that deviates from the agreement, it can be resolved in accordance with the agreement that has been regulated in it, so that the sanctions imposed on the offender, both individuals or groups, are binding and must be obeyed.

\section{CONCLUSION.}

The conflict between the two silat schools that occurred in Madiun, as a form of dynamics in organizational development. Differences of opinion, the interests of each individual as something that usually occurs in social relationships (groups). The conflict between the two silat schools in Madiun was also triggered by differences of opinion regarding the development strategy of the teachings of the loyal silat school. On the one hand, he wants strict selection in recruiting new memberships in order to maintain the quality of his teachings, but on the other hand, he argues that the development strategy is carried out more loosely so that the teaching values can reach a wider range in the community. Efforts to resolve the conflict have been carried out through the reconciliation of the two silat schools, but their implementation is ineffective because of the frequent physical clashes between the two. So the approach to local cultural wisdom can be a supporter of the effectiveness of conflict resolution, because local cultural wisdom upholds the values of harmony, the harmony of coexistence in community life. Local cultural wisdom contains social values and norms that are believed to have the ability to regulate a peaceful and peaceful community life. 


\section{CONFLICT OF INTEREST}

There is no conflict of interest.

\section{ACKNOWLEDGMENTS}

This article is sponsored by the Kemenristik-Dikti Indonesian Research Grants Program.

\section{REFERENCES}

Ghozali, Imam, 2006, Aplikasi Analisis Multivariate Dengan Program SPSS, Badan Penerbit Universitas Diponegoro, Semarang.

Lauer, Robert H, 2001. Perspektif Tentang Perubahan Sosial, Alih Bahasa,. Alimandan S.U (Perpective on Social Change), Penerbit: PT. Rineka. Cipta, Jakarta.

Muarofah, 2014, BAB II KAJIAN TEORI A. Konflik 1. Pengertian Konflik......, digilib.uinsby.ac.id/314/5/Bab\%202.pdf.

Nasikun, 2003, Sistem Sosial Indonesia, Penerbit: PT. Raja Grafindo Persada, Jakarta.

Robert lawing, 1994, Kapital sosial dalam perspektif sosiologik: Suatu pengantar. Penerbit: Gramedia Pustaka Utama, Jakarta.

Setiadi, Elly M \& Usman Kolip, 2011, Pengantar Sosiologi, Jakarta: Penerbit Kencana.

Soebijantoro, dkk, 2012, Rekonsiliasi Konflik Antarperguruan Silat di Madiun (Studi Historis ..., Jurnal sejarah dan Pembelajarannya, Vol 2, No 1,, e-journal.unipma.ac.id/index.php/JA/article/view/770/703

Soerjono Soekanto. 2006. Sosiologi Suatu Pengantar, Penerbit Raja Grapindo Persada, Jakarta. 2017, Struktur Sosial: Pengertian dan Jenisnya, http://sosiologis.com/struktur-sosial.

www.pengertianmenurutahli.net/pengertian-kearifanlokal-secara-umum/) 